DOI $10.14746 /$ ps.2015.1.34

\title{
Przegląd Bezpieczeństwa Wewnętrznego. Wydanie specjalne - slużby wschodnie, Agencja Bezpieczeństwa Wewnętrznego, Warszawa 2013, ss. 220.
}

W związku z obecną sytuacją międzynarodową wokół Ukrainy warto zwrócić uwagę na wydanie specjalne Przegladu Bezpieczeństwa Wewnętrznego poświęcone wschodnim służbom specjalnym, które ukazało się w październiku 2013 roku. Eksperci Ośrodka Studiów Wschodnich im. Marka Karpia oraz Agencji Bezpieczeństwa Wewnętrznego poruszają w nim zagadnienia związane $\mathrm{z}$ bezpieczeństwem wewnętrznym wschodnich sąsiadów Polski oraz roli odgrywanej przez służby specjalne w jego kształtowaniu.

Recenzowany tom zawiera dwanaście artykułów. Otwierają go artykuły przedstawiające analizy dotyczące pozycji służb specjalnych w systemach politycznych Białorusi, Rosji i Ukrainy oraz charakterystyki największych służb Rosji i Ukrainy oraz ich znaczenia dla polityki bezpieczeństwa wewnętrznego państwa. W dalszej części prezentowane są założenia rosyjskiej ustawy o działalności operacyjno-rozpoznawczej oraz analiza aktywności rosyjskich służb specjalnych na terenie Polski i Czech. Tom zamykają trzy artykuły dotyczące działalności tzw. nielegałów na terenie Europy Zachodniej, legalnych rezydentur zagranicznych wywiadu KGB w latach 1954-1991 oraz koncepcji ,neobizantyzmu”. Uzupełnienie publikacji stanowi aneks z thumaczeniami ustaw o działalności operacyjno-rozpoznawczej wschodnich sąsiadów Polski: Rosji, Ukrainy i Białorusi. Motywem przewodnim tomu są oczywiście służby specjalne Rosji. $\mathrm{Z}$ tego powodu dwa pierwsze rozdziały tomu zostały poświęcone analizie ich roli w rosyjskim systemie politycznym oraz Federalnej Służbie Bezpieczeństwa, czyli największej rosyjskiej służbie specjalnej.

W rozdziale pierwszym eksperci OSW opisują rolę służb specjalnych w systemie politycznym Federacji Rosyjskiej. Po chwilowej destabilizacji związanej z szukaniem nowego modelu dla sektora bezpieczeństwa wewnętrznego Rosji w pierwszej połowie lat 90 . XX w., powrócono do koncentracji głównych zadań związanych z bezpieczeństwem państwa w strukturze Federalnej Służby Bezpieczeństwa. Od tego momentu model sektora bezpieczeństwa wewnętrznego Rosji zaczął się na nowo stabilizować i został on ugruntowany w latach 2003-2004.

Autorzy w swoim opracowaniu w przejrzysty sposób prezentują otoczenie prawne służb specjalnych Rosji, krótkie charakterystyki poszczególnych służb oraz źródła finansowania ich działalności.

Znaczenie służb specjalnych w systemie politycznym Rosji jest nad wyraz duże. Struktury państwowe w znacznym stopniu kontrolowane są przez ludzi powiązanych ze służbami specjalnymi, dzięki czemu mogą one chronić i kształtować interesy sektora bezpieczeństwa zarówno w sferze politycznej, jak i ekonomicznej. Symbolem tej symbiozy jest prezydent Władimir Putin.

Rozdział drugi przedstawia główną spadkobierczynię Komitetu Bezpieczeństwa Państwowego, czyli Federalną Służbę Bezpieczeństwa. Autor, obok otoczenia prawnego i charakterystyki tej służby, w ciekawy sposób opisuje FSB jako instrument kształtowania rosyjskiego systemu władzy, który przez jego „militaryzację” powstrzymuje dezintegrację państwa rosyjskiego.

Kolejne trzy rozdziały zostały poświęcone roli służb specjalnych w systemach politycznych Ukrainy i Białorusi. W rozdziale trzecim autorzy szczegółowo opisują służby specjal- 
ne Ukrainy - zwłaszcza ich otoczenie polityczne i prawne, w których funkcjonują, system kontroli i nadzoru oraz charakterystykę i struktury poszczególnych służb. Rozdział czwarty został poświęcony najważniejszej służbie specjalnej Ukrainy, tj. Służbie Bezpieczeństwa Ukrainy, oraz jej roli w systemie bezpieczeństwa wewnętrznego państwa. Autorzy podkreślają, że zbyt szeroki zakres kompetencyjny SBU stwarza ryzyko wykorzystywania jej do wywierania wpływu na funkcjonowanie państwa. Dlatego też w 2012 r. władze państwowe Ukrainy rozpoczęły reformowanie SBU, których celem jest przekształcenie tej służby w organizację wpisującą się w demokratyczne przemiany zachodzące do tej pory na Ukrainie. Jednakże obecne próby dezintegracji państwa ukraińskiego mogą się przyczynić do ograniczenia reformy tej służby, jak i całego systemu służb bezpieczeństwa wewnętrznego.

W rozdziale piątym analizie został poddany białoruski system służb specjalnych. Zdaniem Autorek funkcjonowanie białoruskich służb specjalnych jest wypadkową przede wszystkim kilku czynników bądź tendencji, wśród których wyróżniły: autorytaryzm przywódcy państwa, siłę tradycji radzieckiej oraz wykorzystanie rosyjskich wzorców organizacyjno-prawnych.

Szczególnie autorytarny system polityczny Białorusi i wiążące się z nim standardy prawne, w tym brak poszanowania trójpodziału władzy, kształtuje standardy funkcjonowania służb specjalnych. Odzwierciedla to brak zapisów konstytucyjnych kontroli resortów siłowych i służb specjalnych przez prezydenta Białorusi, którąjednak faktycznie sprawuje. Skutkiem czego jest również ich instrumentalne wykorzystywanie w realizacji bieżącej polityki prezydenta Białorusi.

W dwóch kolejnych rozdziałach Autorzy przedstawiają i analizują rosyjskie regulacje prawne z zakresu działalności operacyjno-rozpoznawczej. W każdym państwie powinny istnieć przepisy prawne jasno regulujące zagadnienia działalności operacyjno-rozpoznawczej służb specjalnych. Istnienie takich przepisów ma z jednej strony gwarantować zabezpieczenie praw jednostki, aby wyznaczyć granice ingerencji państwa w prawa człowieka, z drugiej zaś strony ma również zapewnić bezpieczeństwo funkcjonariuszy państwowych oraz skuteczność procesu sądowego. Niestety polskie prawodawstwo nie może się poszczycić ujednoliconymi przepisami w tym zakresie.

W rozdziałach ósmym i dziewiątym Autorzy analizują aktywność rosyjskich służb wywiadowczych w regionie Europy Środkowo-Wschodniej na przykładzie Polski i Czech. Podkreślenia wymaga przede wszystkim współpraca służb wywiadowczych Rosji i Białorusi oraz obszary pozostające w kręgu zainteresowania służb rosyjskich ze względu na interesy polityczne, gospodarcze i militarne Moskwy, ze względu na członkostwo części państw tego regionu w strukturach Unii Europejskiej i Sojuszu Północnoatlantyckiego oraz aspiracji innych przystąpienia do tych struktur. Służby specjalne Rosji szczególnie są zainteresowane politykami energetycznymi poszczególnych państw, co oczywiście wynika $z$ chęci wzmacniania pozycji rosyjskiego sektora energetycznego na rynku europejskim.

W kolejnym rozdziale możemy dowiedzieć się o tak wyrafinowanym rodzaju działalności wywiadowczej, jaką jest lokowanie agentury głęboko zakonspirowanej w społecznościach poszczególnych państw zachodnich. Autor posłużył się przykładem małżeństwa Anschlagów, będącym w rzeczywistości parą rosyjskich nielegałów. Na przykładzie tej historii warto zwrócić uwagę na znaczenie współpracy międzynarodowej w celu zweryfikowania pozyskanych informacji. Skuteczną wymianę informacji w ramach współpracy międzynarodowej buduje się dzięki zasadzie wzajemności i uzyskaniu informacji zwrotnej. 
Bardzo interesująca analiza została przedstawiona w rozdziale jedenastym, która opisuje funkcjonowanie legalnych rezydentur zagranicznych wywiadu KGB w latach 1954-1991. Pod pojęciem legalnej rezydentury rozumie się agenturę działającą pod osłoną instytucji funkcjonujących oficjalnie na terenie obcego państwa. Zazwyczaj były to przedstawicielstwa dyplomatyczne, konsularne i handlowe, lecz były to także agencje prasowe, redakcje gazet, instytucje kulturalne i naukowe, a także biura podróży bądź organizacje społeczne. Artykuł zawiera również aneks, w którym zostały przedstawione instytucje służące przykryciu działalności wywiadowczej oficerów służb specjalnych ZSRR.

Dla czytelnika interesujące okażą się również charakterystyki dotyczące podziału między oficerów wywiadu funkcji dyplomatycznych bądź konsularnych w zależności od zadań realizowanych w ramach rezydentury, a także w jaki sposób służby kontrwywiadowcze krajów przyjmujących analizują zachowania potencjalnych szpiegów.

W ostatnim rozdziale tomu Autor opisał próby stworzenia przez rosyjskie elity polityczne nowych koncepcji skutecznej polityki zagranicznej mających na celu odbudowanie prestiżu i pozycji Rosji jako jednego z czołowych mocarstw światowych.

Nostalgia społeczeństwa rosyjskiego za imperialnym statusem Rosji w stosunkach międzynarodowych jest głównym motorem podejmowanych przez Kreml decyzji o ekspansywnym charakterze wobec jej najbliższego otoczenia geopolitycznego, w tym oczywiście Ukrainy. Autor przytacza cztery główne nurty rosyjskiej myśli geopolitycznej, tj. izolacjonizm, neobizantyzm, eurazjanizm oraz okcydentalizm.

Neobizantyzm, którego dotyczy opracowanie, nawiązuje do XIX-wiecznego nurtu bizantyzmu, którego twórcą był Konstantin Leontjew. Zgodnie z filozofią bizantyzmu o silnej Rosji stanowi dziedzictwo kulturowe Bizancjum, zgodnie z którym Moskwa miała stanowić ośrodek dominujący zarówno w sferze politycznej, jak i religijnej. Dlatego też potęga państwa miała się opierać na silnej władzy państwowej oraz prawosławiu, których emanacjami mają być silny władca oraz ortodoksyjny patriarcha. Współcześnie koncepcja neobizantyzmu, podobnie jak koncepcja bizantyzmu, opiera się na przyjęciu postawy konfrontacyjnej wobec Zachodu poprzez krytykę i negację przypisywanych jemu cech, czyli liberalizmu, materializmu, indywidualizmu oraz kapitalizmu.

Koncepcja neobizantyzmu pozwala władzy rosyjskiej na skuteczną komunikację ze społeczeństwem, które chce utożsamiać się z silnym państwem opartym na ortodoksyjnym chrześcijaństwie. Dzięki niemu Kreml uzasadnia również swoją ekspansjonistyczną politykę, która ma być realizowana poprzez wykorzystanie skutecznych metod angażujących jak najmniej sił i środków.

Wspólna publikacja OSW i ABW stanowi bardzo ciekawy materiał wyjściowy do dalszej dyskusji osób zainteresowanych zagadnieniami bezpieczeństwa - zarówno naukowców i ekspertów, jak i dziennikarzy i publicystów. Należy podkreślić, że publikacja ta jest jawna pomimo tego, że porusza kwestie pozostające na co dzień tajemniczymi i nie dopowiedzianymi. Na polskim rynku wydawniczym materiał analityczny zebrany w recenzowanym tomie można uznać za unikalny.

Współpraca obu instytucji analityczno-informacyjnych RP stanowi znakomite połączenie informacji pochodzących z analizy źródeł otwartych, jak i dokonanych ich interpretacji na podstawie dostępu do informacji niejawnych. Uważam, że obydwie instytucje gwarantują rzetelność danych przedstawionych w poszczególnych analizach cząstkowych opracowania. Publikacja ta na pewno stanowi bardzo interesujący element polityki informacyjnej ABW. Zaprezentowanie jej szerszemu gronu - zwłaszcza w związku z obecną aktywnością 
Federacji Rosyjskiej w stosunkach międzynarodowych w obszarach: politycznym, militarnym, dyplomatycznym oraz wywiadowczym - należy uznać za pożądany wstęp do szerszej inicjatywy: kompleksowej profilaktyki kontrwywiadowczej skierowanej na każdy poziom administracji państwowej oraz do spółek Skarbu Państwa i przedsiębiorstw aktywnych na rynkach państw Europy Wschodniej.

Otwarcie się Agencji Bezpieczeństwa Wewnętrznego na współpracę z ośrodkami analitycznymi i naukowymi to właściwy kierunek, dzięki któremu otaczająca nas rzeczywistość zostanie opisana również z punktu widzenia funkcjonowania w niej tak enigmatycznych instytucji, jak służby specjalne. Tego typu starania czynione są już od wielu lat w USA, Wielkiej Brytanii czy Holandii. Redakcja Przegląu Bezpieczeństwa Wewnętrznego w niedalekiej przyszłości mogłaby przygotować swoim czytelnikom kolejne wydania w duchu recenzowanego przeze mnie numeru specjalnego PBW. Mogłoby one dotyczyć analizy aktywności rosyjskich służb specjalnych w innych państwach członkowskich Unii Europejskiej i Sojuszu Północnoatlantyckiego na przestrzeni ostatniego ćwierćwiecza oraz w przededniu i podczas agresji Rosji na Ukrainę, ze szczególnym uwzględnieniem Brukseli (siedziby UE i NATO) jako światowej stolicy szpiegów.

Maciej KLUCZYŃSKI

Warszawa 